\title{
Діагностична і прогностична цінність прокалыцитоніну і окремих загальноклінічних обстежень у ранній діагностиці інфікованого гострого некротичного панкреатиту
}

\author{
I. YA. DZYUBANOVSKYI, A. I. BANADYHA \\ SHEI "Ternopil State Medical University by I. Ya. Horbachevsky"
}

\author{
DIAGNOSTIC AND PROGNOSTIC VALUE OF PROKALTSYTONIN IN INDIVIDUAL AND \\ GENERAL CLINICAL EXAMINATIONS IN EARLY DIAGNOSIS OF ACUTE INFECTED NECROTIZING \\ PANCREATITIS
}

\begin{abstract}
У статті відображені результати визначення прокальцитоніну у хворих на гострий панкреатит (ГП) 3 метою ранньої діагностики і прогнозування інфікованого гострого некротичного панкреатиту (ГНП). Одержані результати порівнювались з іншими лабораторними показниками, даними УЗД та комп’ютерної томографії (КТ) черевної порожнини при тяжкому та нетяжкому панкреатиті. Лабораторні методи обстеження проводились на 1-шу, 2-гу, 3-тю, 7-му доби захворювання, а інструментальні при госпіталізації і в динаміці залежно від ситуації. Проведено кореляційний аналіз між клінічними і лабораторними показниками. Діагностична цінність УЗД у діагностиці гострого панкреатиту (ГП) була на рівні 75,67 \%, що зумовлено малоінформативністю методу при метеоризмі. Візуалізація змін ПЗ при КТ, що діагностично була достовірна, становила 86,66 \%. Тому визначення прокальцитоніну в поєднанні з іншими лабораторними показниками є діагностично цінним у ранній діагностиці ГП та інфікованого ГНП зокрема.

The article reflects the results of determination of prokaltsytonin in patients with acute pancreatitis (AP) for early diagnosis and prediction of infected acute necrotizing pancreatitis (ANP). The results were compared with other laboratory parameters, ultrasound and computer tomography (CT) of the abdominal cavity with mild and severe pancreatitis. Laboratory examination methods were carried out on the 1st, $2 \mathrm{nd}$, 3rd, 7 th day of the disease, instrumental methods of diagnostic at the start of disease and in dynamics due to situation.Correlation analysis between clinical and laboratory parameterswas made. The diagnostic value of ultrasonography in the diagnosis of acute pancreatitis was at 75,67\% due to low informativity because of flatulence. Visualization of changes in CT software was diagnostically 86,66 \%. Therefore, the definition of prokaltsytonin together with other laboratory parameters is diagnostically valuable in early diagnosis of AP as well as in infected ANP.
\end{abstract}

Постановка проблеми і аналіз останніх досліджень та публікацій. Питання лікування гострого панкреатиту (ГП) все частіше виникає перед спеціалістами хірургічного профілю, а саме: захворювання займає третє місце серед невідкладних захворювань органів черевної порожнини після гострого апендициту й гострого холециститу і становить від 4 до $16 \%$ [2]. Захворюваність на ГП за останні два десятиліття зросла удвічі й невпинно зростає у багатьох розвинених країнах, уражаючи різні верстви населення, знижуючи працездатність та інвалідизуючи людей працездатного віку - від 21 до 60 років, найчастіше 30-50 років, що зумовлює соціально-економічне значення проблеми $[2,4,5,6]$. У групі до 40 років переважають чоловіки (69 \%) [2, 3]. Частота виникнення панкре- атиту становить від 8 до 13 на 100000 населення, що складає 12-20\% пацієнтів хірургічного профілю [6]. У 15-20 \% випадків перебіг панкреатиту ускладнюється субтотально-тотальним панкреонекрозом з летальністю від 24 до 80 \% [13]. Незважаючи на використання сучасного лікувальнодіагностичного потенціалу, загальна летальність при гострому некротичному панкреатиті (ГНП) та ураженні заочеревинної клітковини й на сьогодні залишається дуже високою та в середньому складає 15-25 \% при стерильному і 30-70 \% - при інфікованому ГНП. Тяжкі форми ГП супроводжуються летальністю до 85,7 \% [5, 7, 10, 12]. На сьогодні як в Україні, так і за кордоном ще не існує єдиної доктрини консервативного та хірургічного лікування ГНП [5, 10, 11, 12]. Наявні в літературі 
повідомлення часто суперечливі. Предметом дискусій залишаються прогнозування, вибір показань та термінів виконання хірургічних втручань, обсяг і технічні прийоми операційних втручань, а також низка питань щодо консервативного лікування [1, 9]. Хоча інструментальна візуалізація підшлункової залози досягла досить високого рівня, питання неінвазивної діагностики інфікованого ГНП є не повністю вирішеним $[7,8]$. Швидке, точне та своєчасне визначення характеру та ступеня деструкції підшлункової залози й заочеревинної клітковини, а також пошук “інструментів” для прогнозування перебігу ГНП є одним із можливих шляхів вирішення проблеми лікування даного захворювання [5, 9]. Зокрема, діагностична цінність прокальцитоніну - біохімічного маркера ранньої діагностики сепсису в хірургічній панкреатології ще достатньо не вивчена, а тому науковий пошук у даній галузі є більш ніж доцільний.

Мета роботи: покращити результати лікування пацієнтів із гострим інфікованим некротичним панкреатитом шляхом удосконалення його ранньої діагностики, можливості прогнозування перебігу захворювання.

Матеріали і методи. Проаналізовано клінічну картину, проведено комплексне обстеження й лікування 101 хворого з ГНП, що перебували на стаціонарному лікуванні у хірургічному відділенні й BAIT K3 ТОР “Тернопільська університетська лікарня” протягом 2012-2015 рр. Значну більшість обстежених хворих склали чоловіки - 73 пацієнти (72,23 \%), жінок було 28 (27,72 \%). За віком пацієнти розподілились таким чином: 18-59 років - 69 (68,31 \%), 60-74 роки - 24 (23,76 \%), 75 і старші 8 (7,92 \%). У групі віком 18-59 років переважали чоловіки - 59 (85,5 \%), жінок було 10 (14,49 \%). У групі віком 60-74 роки переважали жінки - 14 (58,33 \%), чоловіків було 10 (41,67 \%), у групі віком 75 років і старші - по 50 \% чоловіків і жінок. Середній вік пацієнтів становив $(43,4 \pm 1,44)$ року в першій групі дослідження та $(48,60 \pm 1,57)$ - у другій групі відповідно.

При проведенні аналізу досліджуваних груп за віком вірогідної різниці не виявлено, що свід- чить про порівнянність досліджуваних груп за віковою характеристикою. Рівень прокальцитоніну в крові визначали у 20 хворих із тяжким і критичним ГП на 1-шу і 7-му доби, які склали надалі II групу. Статистичну обробку результатів виконано у відділі системних статистичних досліджень університету в програмному пакеті Statsoft STATISTICA.

Результати досліджень та їх обговорення. У хворих обох груп проведено повний комплекс клінічних і лабораторно-інструментальних обстежень. Щодо етіологічного чинника панкреатиту розподіл був таким (табл. 1), що суттєво переважали аліментарні фактори. При цьому алкогольний $(85,71$ \%) та аліментарний (73,97 \%) фактори переважали у чоловіків, тоді як біліарні чинники - виключно у жінок (100 \%).

Розпочали лікування із вторинного рівня надання допомоги 58 пацієнтам (57,43 \%), які в подальшому за згодою переведені на лікування на третинний рівень. Одразу госпіталізували в Тернопільську університетську лікарню 43 хворих (42,57 \%). Первинну госпіталізацію проведено до 6 год у 21 хворого (20,79 \%), від 6 до 24 год - у 26 (25,74 \%), пізніше 24 год - у 54 (53,46 \%) пацієнтів.

При проведенні УЗД при госпіталізації в стаціонар у пацієнтів I групи виявлено зміни в підшлунковій залозі, що характерні для гострого панкреатиту, - 15 пацієнтів (88 \%), - це були хворі на ГП середньої тяжкості (наявність стерильного (пери)панкреатичного некрозу); у 2 хворих на ГП середньої тяжкості дане дослідження не було інформативним. При проведенні УЗД у пацієнтів II групи хибнонегативні результати були у 7 хворих (35 \%). Основні труднощі, що виникли, були пов’язані з явищами вираженого метеоризму, особливо гіперпневматозу поперечноободової кишки та надмірною масою тіла пацієнтів, що часто поєднувались. Зі сказаного випливає, що в першу добу від початку захворювання у пацієнтів із ГП середнім, тяжким і критичним діагностична цінність сонографічної діагностики знижена порівняно з легким ГП, що може призводити до помилок у діагностиці ГП. Комп’ютерну томографію (КТ)

Таблиця 1. Етіологічна структура різних форм панкреатиту (абс.,\%)

\begin{tabular}{||l|c|c|c|c||}
\hline \multicolumn{1}{|c|}{ Чинник } & ГП середньої тяжкості & Тяжкий ГП & Критичний ГП & Всього \\
\hline Аліментарний & $22(88 \%)$ & $35(85,36 \%)$ & $16(45,71 \%)$ & $73(72,27 \%)$ \\
\hline Біліарний & $1(4 \%)$ & $2(4,88 \%)$ & $6(17,14 \%)$ & $9(8,91 \%)$ \\
\hline Алкогольний & $2(8 \%)$ & $3(7,31 \%)$ & $9(25,71 \%)$ & $14(13,86 \%)$ \\
\hline Ідіопатичний & 0 & $1(2,43 \%)$ & $4(11,42 \%)$ & $5(4,95 \%)$ \\
\hline Всього & $25(100 \%)$ & $41(100 \%)$ & $35(100 \%)$ & $101(100 \%)$ \\
\hline \hline
\end{tabular}


проводили у 15 хворих II групи з тяжким (9) і критичним (6) ГП, діагностична цінність у хворих із критичним ГП мала місце у 83,33 \% (5 пацієнтів), із тяжким - у 88,88 \% (8 пацієнтів).

Кількість оперованих пацієнтів становила 41 (40,59 \%), обсяг операційного втручання представлений у таблиці 2.

За результатами операційного втручання, у 22 пацієнтів діагностований інфікований панкреонекроз (табл. 3), післяопераційна летальність становила $16,83 \%$.

В рамках даного дослідження було відібрано 37 пацієнтів, яким виконували розширений комплекс параклінічного обстеження. На підставі тяжкості стану пацієнтів їх розподілено на дві групи відповідно до Міжнародного консиліуму 2012 р., що є доповненням Атланти 1992 р.: хворі на легкий ГП (відсутність (пери)панкреатичного некрозу та органної недостатності) і середньої тяжкості (наявність стерильного (пери)панкреатичного некрозу та/або переміжної органної недостатності) становили I групу дослідження (n=17); хворі на тяжкий ГП (наявність або інфікованого (пери)панкреатичного некрозу, або стійкої органної недостатності) і критичний ГП (наявність інфікованого (пери)панкреатичного некрозу і стійкої органної недостатності) становили II групу дослідження $(\mathrm{n}=20)$. При цьому пацієнтів із ГП середньої тяжкості - 17, тяжким - 14, критичним - 6 осіб.

Тобто, ступінь тяжкості визначали на основі наявності локальної детермінанти, до якої належить некроз підшлункової залози і/або некроз перипанкреатичної клітковини, що представлено терміном “(пери)панкреатичний некроз”, та системної детермінанти, тобто, певного ступеня органної дисфункції внаслідок ГП.

3 метою визначення діагностичної і прогностичної цінності окремих лабораторних параметрів у всіх пацієнтів I і II груп було проаналізовано 19 показників, що відображають стан функціо- нування окремих систем організму на 1-шу, 2-гу, 3-тю, 7-му доби захворювання, та окремо визначали прокальцитонін усім хворим II групи.

Окрему підгрупу склали хворі - 5 чоловік, - які були оперовані впродовж перших 3 діб від моменту госпіталізації, коли ранні операційні втручання були мотивовані ускладненнями панкреатиту, перевагою локальних проявів захворювання i показання визначались рішеннями консиліуму. Рівні прокальцитоніну в даного контингенту хворих були відчутно вищими, ніж в інших групах $((7,32 \pm 3,0) \mathrm{ng} / \mathrm{ml}, \mathrm{p}<0,05)$, що в комплексі з іншими клініко-лабораторними даними враховували консилярно i призначали активну хірургічну тактику лікування. В іншу підгрупу - 13 пацієнтів - ввійшли оперовані хворі, у яких при госпіталізації переважали системні прояви захворювання при відсутності виражених локальних хірургічних детермінант панкреатиту (згідно 3 доповненою класифікацією Атланти 2012 р.). Відповідно, рівні прокальцитоніну в цих пацієнтів не були високими: $(0,45 \pm 0,08) \mathrm{ng} / \mathrm{ml}$, $\mathrm{p}>0,05$. Це свідчить про асептичність запалення підшлункової залози, і тому таким хворим проводили спочатку консервативну терапію. У даних хворих низькі рівні цього показника були прогностично сприятливими, що дало змогу контролювати правильність призначення терапії, вчасно реагувати хірургічними втручаннями.

У 5 пацієнтів (16,6 \%) рівень ферменту становив надвисокі показники: $(7,32 \pm 3,0) \mathrm{ng} / \mathrm{ml}$, $\mathrm{p}<0,05$, що достовірно свідчило про інфікованість запалення, і комплексні показання до операційного втручання в перші 3 доби були саме в цих хворих. Тобто, це був контингент хворих із пізньою госпіталізацією в хірургічний стаціонар, у якого був у розпалі період гнійно-септичних ускладнень ГНП, відповідно, приєднувався синдром системної запальної відповіді (SIRS). Прокальцитонін був у даних пацієнтів досить показовим маркером

Таблиця 2. Обсяг операційних втручань при різного ступеня тяжкості гП (абс.,\%)

\begin{tabular}{||l|c|c|c|c||}
\hline \multicolumn{1}{|c|}{ Обсяг втручань } & ГП середньої тяжкості & Тяжкий ГП & Критичний ГП & Всього \\
\hline Закриті дренування & $3(60 \%)$ & $3(17,64 \%)$ & $2(10,52 \%)$ & $8(19,51 \%)$ \\
\hline Відкриті дренування & $2(40 \%)$ & $14(82,35 \%)$ & $17(89,47 \%)$ & $33(80,49 \%)$ \\
\hline Всього & $5(100 \%)$ & $17(100 \%)$ & $19(100 \%)$ & $41(100 \%)$ \\
\hline
\end{tabular}

Таблиця 3. Структура тяжкості гострого панкреатиту (абс.,\%)

\begin{tabular}{||l|c|c|c||}
\hline \multicolumn{1}{|c|}{ Тяжкість } & Стерильний панкреонекроз & Інфікований панкреонекроз & Число померлих \\
\hline ГП середньої тяжкості & $27(34,17 \%)$ & 0 & 0 \\
\hline Тяжкий ГП & $31(39,24 \%)$ & $5(22,72 \%)$ & $4(23,52 \%)$ \\
\hline Критичний ГП & $21(26,58 \%)$ & $17(77,27 \%)$ & $13(76,47 \%)$ \\
\hline Всього & $79(100 \%)$ & $22(100 \%)$ & $17(100 \%)$ \\
\hline
\end{tabular}


цього синдрому і тим чинником, на який зважав консиліум у виборі лікувальної тактики (табл. 4). Як виявилось, рішення були абсолютно правильними - інтраопераційна картина відповідала очікуваному.

Серед неоперованих рівень прокальцитоніну був нормальним $((0,74 \pm 0,26)$ нг/мл, $>>0,05)$, i захворювання піддалось консервативному лікуванню, яке включало комплексну антисекреторну, дезінтоксикаційну, антибактеріальну терапію. Так, на фоні вчасної і адекватної симптоматичної терапії хворі одужали й були виписані.

Основні показники, що відображають стан функціонування окремих систем організму на 1-шу, 2-гу, 3-тю, 7-му доби захворювання, піддали статистичній обробці із використанням критерію Стьюдента, проведено оцінку вірогідності відмінностей перерахованих параметрів у хворих I та II груп. Із усіх 19 проаналізованих лабораторних параметрів виділено 8, які мають вірогідну відмінність ( $<0,05)$. Середні показники у хворих, подано в таблиці I і II груп, що мають статистично значущу відмінність, подано в таблиці 5.

Середній рівень амілази крові й діастази сечі в обох групах (рис. 1, 2) був максимальним на 1-шу добу захворювання і знижувався до 3-х діб (у II групі навіть нижче норми), що зумовлено зовнішньосекреторною недостатністю залози внаслідок некрозу паренхіми.

Середні показники глюкози крові були вищими від норми в обох групах протягом всіх 7 днів, що теж зумовлено проявами панкреонекрозу (рис. 3.)

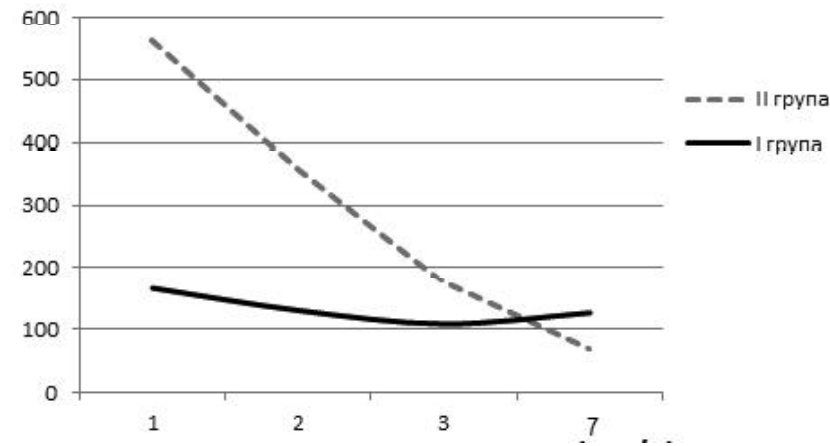

Рис. 1. Середні рівні амілази крові (Оділ) у хворих I i II груп на 1-шу, 2-гу, 3-тю, 7-му доби.

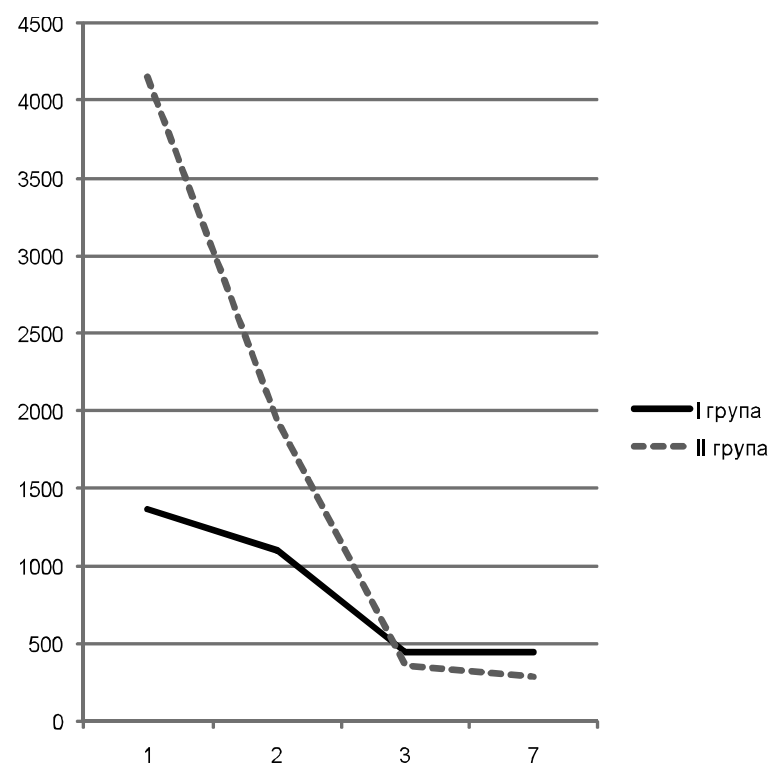

Рис. 2. Середні рівні діастази сечі (ОД/л) у хворих I i II груп на 1-шу, 2-гу, 3-тю, 7-му доби.

Таблиця 4. Рівень прокальцитоніну в крові хворих залежно від виду лікування (нг/мл)

\begin{tabular}{||l|c|c|c||}
\hline \multicolumn{1}{|c|}{ Вид лікування } & Кількість хворих & M+m & Критерій достовірності \\
\hline Оперовані $<72$ год від госпіталізації & 5 & $7,32 \pm 3,0$ & $\mathrm{p}<0,05$ \\
\hline Оперовані $>72$ год від госпіталізації & 13 & $0,45 \pm 0,08$ & $\mathrm{p}>0,05$ \\
\hline Консервативна терапія & 3 & $0,74 \pm 0,26$ & $\mathrm{p}>0,05$ \\
\hline Контрольна група & 10 & $0,96 \pm 0,17$ & \\
\hline
\end{tabular}

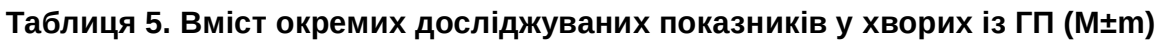

\begin{tabular}{||l|c|c|c||}
\hline \multicolumn{1}{|c|}{ Показник } & І група, $\mathrm{n}=17$ & II група, $\mathrm{n}=20$ & Критерій достовірності \\
\hline Амілаза, Од/л & $132,50 \pm 23,48$ & $290,71 \pm 46,67$ & $\mathrm{p}<0,01$ \\
\hline Діастаза, Од/л & $837,52 \pm 185,82$ & $1680,47 \pm 380,33$ & $\mathrm{p}<0,05$ \\
\hline Глюкоза, ммоль/л & $7,52 \pm 0,33$ & $7,25 \pm 0,33$ & $\mathrm{p}<0,01$ \\
\hline Білірубін, ммоль/л & $15,77 \pm 1,10$ & $21,55 \pm 2,55$ & $\mathrm{p}<0,05$ \\
\hline АлАТ, Од/л & $32,36 \pm 2,62$ & $78,60 \pm 14,6$ & $\mathrm{p}<0,01$ \\
\hline АсАТ, Од/л & $33,03 \pm 2,16$ & $69,73 \pm 12,9$ & $\mathrm{p}<0,01$ \\
\hline Лейкоцити,109 & $7,46 \pm 0,32$ & $12,09 \pm 0,70$ & $\mathrm{p}<0,01$ \\
\hline Гемоглобін, г/л & $116,34 \pm 2,33$ & $114,4 \pm 3,18$ & $\mathrm{p}>0,05$ \\
\hline Загальний білок, г/л & $62,66 \pm 0,92$ & $52,64 \pm 1,35$ & $\mathrm{p}<0,01$ \\
\hline \hline
\end{tabular}




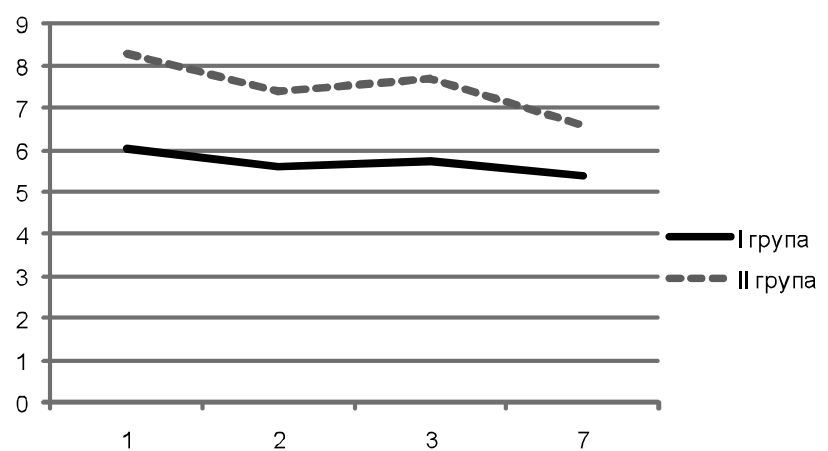

Рис. 3. Середні рівні глюкози крові (ммоль/л) у хворих I і II груп на 1-шу, 2-гу, 3-тю, 7-му доби.

Синдром цитолізу був характерний для хворих II групи на початку захворювання з поступовим зниженням (рис. 4, 5).

Запальні зміни периферичної крові проявлялись більшою мірою у хворих II групи (рис. 6).

Слід звернути увагу на те, що рівні білірубіну в I групі в середньому були в межах норми, коли у II групі спостерігалась тенденція до зростання цього показника внаслідок прогресування захворювання. Середні рівні гемоглобіну і загального білка мали тенденцію до зниження протягом усіх 7 діб.

В обох групах хворих сильні кореляційні зв’ язки на 1-шу добу захворювання утворювались

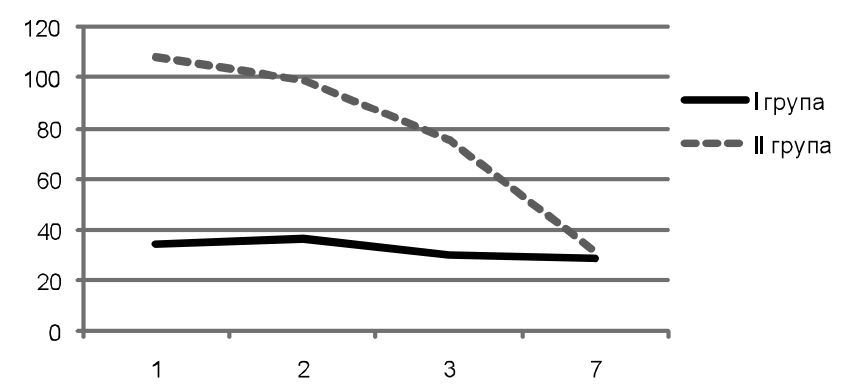

Рис. 4. Середні рівні АлАТ у хворих I і II груп на 1-шу, 2-гу, 3-тю, 7-му доби.

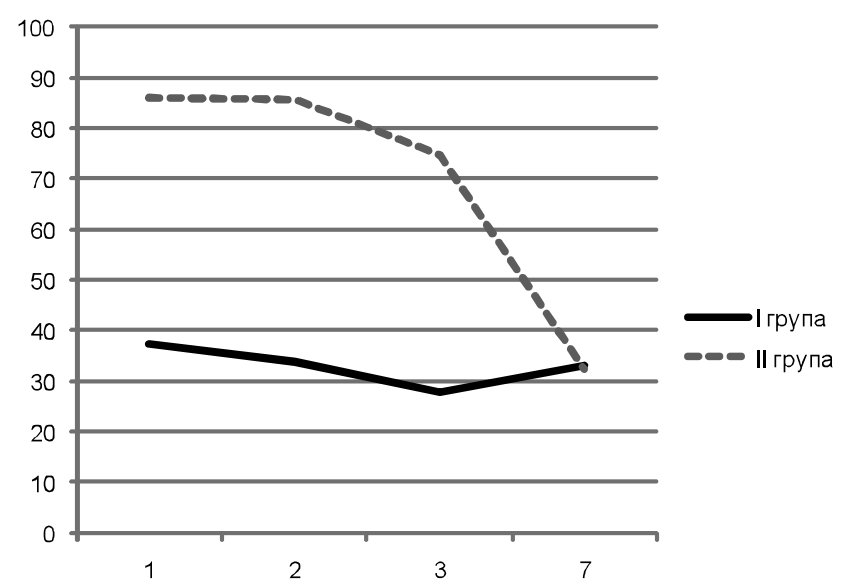

Рис. 5. Середні рівні АсАТ (ммоль/л) у хворих I і II груп на 1-шу, 2-гу, 3-тю, 7-му доби.



Рис. 6. Середні рівні лейкоцитів крові $\left(10^{9}\right)$ у пацієнтів I і II груп на 1-шу, 2-гу, 3-тю, 7-му доби.

між рівнями амілази крові й діастази сечі: $\mathrm{r}=0,75 \mathrm{i}$ r=0,73 у I і II групах відповідно. На 2-гу добу сила зв'язку була середня: r=0,61 у I i r=0,65 у II групі, а на 3-тю добу знову ставала сильною в обох групах: r=0,76 i r=0,78 у I і II групах відповідно. На 7-му добу в I групі сильний зв’язок зберігався між даними показниками: $\mathrm{r}=0,75$. На 7-му добу простежувався середній кореляційний зв’ язок між рівнями діастази сечі і глюкози у II групі: r=0,64. Слід зазначити, що сильний кореляційний зв’язок спостережено у I групі на 1-шу добу між такими клінічними показниками, як здуття живота i метеоризм, r=0,88, АлТ і АсТ, r=0,87. У ІІ групі на 1-шу добу між здуттям живота і блюванням був сильний кореляційний зв'язок: $r=0,79$, як і між метеоризмом та здуттям живота: $r=0,76$. Також у II групі на 1-шу добу між такими симптомами, як Мейо-Робсона та здуттям живота, виникав сильний зв'язок: r=0,79; і між симптомом Воскресенського та здуттям живота: $r=0,79$. Найбільша кількість кореляційних зв'язків фокусувалась навколо рівня амілази крові, діастази сечі, що свідчить про їх провідну роль у можливості прогнозування розвитку ГНП. Отримані одним із системних методів аналізу дані підтверджують припущення стосовно ключової значимості цих параметрів у прогнозуванні перебігу ГП.

Проаналізувавши отримані дані, ми встановили, що при визначенні рівня прокальцитоніну, амілази, глюкози крові, діастази сечі при госпіталізації діагноз ГП підтверджено в 17 (85 \%) та 15 (88,23 \%) випадках I та II груп відповідно.

Показники рівня прокальцитоніну, глюкози крові корелювали між собою, що свідчить про високу діагностичну цінність визначення рівня прокальцитоніну та вищевказаних лабораторних показників для ранньої діагностики ГНП.

Слід зазначити таке: якщо враховувати результати визначення прокальцитоніну ізольовано від інших лабораторних показників, констатовано, що в пацієнтів II групи (тяжкий і критичний ГП) даний тест на 1-шу, 2-гу, 3-тю доби був позитивним у 14 (70 \%) спостереженнях. 
Висновки. 1. Завдяки визначенню провідних біохімічних показників (амілази, глюкози кровi, діастази сечі, прокальцитоніну) при госпіталізації діагноз ГП підтверджено в 17 (85 \%) та 15 (88,23 \%) випадках I та II груп відповідно, що відображає роль вищевказаних лабораторних показників для ранньої діагностики ГП.

2. Якщо враховувати результати визначення прокальцитоніну, констатовано, що у пацієнтів II групи даний показник на 1-шу-7-му доби був достовірно високим - у 14 (70 \%) спостереженнях, у яких встановлено діагноз ГНП, що свідчить про високу діагностичну цінність визначення рівня прокальцитоніну для ранньої діагностики ГНП.

3. При проведенні УЗД у пацієнтів II групи хибнонегативні результати були у 7 хворих (35 \%). Основні труднощі, що виникли, були пов'язані з явищами вираженого метеоризму, особливо гіперпневматозу поперечноободової кишки, та надмірною масою тіла пацієнтів, що часто поєднувались.

\section{СПИСОК ЛІТЕРАТУРИ}

1. Василюк С. М. Комплексне хірургічне лікування хворих на стерильний аліментарний панкреонекроз із ферментативним перитонітом / С. М. Василюк, М. Д. Василюк // Хірургія України. - 2009. - № 1. - С. 51-55.

2. Патогенетичний підхід до лікування гострого некротичного панкреатиту / О. І. Дронов, І. О. Ковальська, В. Я. Шпак [та ін.] // Клінічна хірургія. - 2007. - № 9. - С. 25-27.

3. Гострий некротичний панкреатит: сучасні підходи до хірургічного лікування / В. М. Копчак, І. В. Хомяк, К. В. Копчак [та ін.] // Харк. хірург. школа. - 2008. - № 2. - С. 109-111.

4. Конькова М. В. Диагностическая и интервенционная сонография в неотложной абдоминальной хирургии / М. В. Конькова. - Донецк : Новый мир, 2005. - С. 104-118.

5. Копчак В. М. Диференційоване етапне хірургічне лікування гострого некротичного панкреатиту / В. М. Копчак, І.В.Хомяк // Вестник клуба панкреатологов. - 2011. - С. $42-45$.

6. Ничитайло М. Ю. Панкреонекроз. Профілактика інфікування та лікування інфекційних ускладнень / М. Ю. Ничитайло, О. П. Кондратюк, Ю. В. Снопок // Український журнал хірургії. - 2009. - № 4. - С. 104-108.

7. Пропп А. Р. Клинические параллели компьютерной томографии и интраоперационных кистозных образований поджелудочной железы / А. Р. Пропп // Вестник хирургии им. И. И. Грекова. - 2011. - Т. 170.
4. Зважаючи на сильний кореляційний зв'язок, насамперед між амілазою крові та діастазою сечі, а також діагностично цінні результати визначення прокальцитоніну, ці показники слід враховувати при верифікації діагнозу ГНП.

5. Враховуючи наявність сильних кореляційних зв'язків між окремими клінічними симптомами, їх теж необхідно враховувати у діагностичнолікувальному процесі.

6. Прогресуюче зниження рівня гемоглобіну, загального білка в крові потребує корекції протокольної терапії.

Перспективи подальших досліджень. При верифікації інфікованого ГНП прокальцитонін $є$ допоміжним неінвазивним маркером, який дає змогу краще орієнтуватись у хірургічній тактиці лікування. Проте відкритими залишаються ще багато питань, зокрема співвідношення даного біохімічного субстрату з різними прозапальними медіаторами, 3 інкреторною та екскреторною функціями ПЗ, що потребує продовження досліджень у цій галузі.

8. Савельев В. С. Панкреонекрозы / В. С. Савельев, М. И. Филимонов, С. З. Бурневич. - М. : ООО “Медицинское информационное агентство”, 2008. - 264.

9. Low mortality and high morbidity in severe acute pancreatitis with out organ failure: acase for revising the Atlanta classification to include "moderately severe acute pancreatitis"/ S. S. Vege, T. B. Gardner, S. T. Chari [et al.] // Am. J. Gastroenterol. - 2009. - Vol. 104. - P. 710-715.

10. Larvin M. Management of infected pancreatic necrosis / M. Larvin // Curr. Gastroenterol. Rep. - 2008. - Vol. 10, №. 2. - P. 107-114.

11. Peroral transgastric/transduodenal necrosectomy: success in the treatment of infected pancreatic necrosis / J. Escourrou, H. Hehab, L. Buscail [et al.] // Ann. Surg. - 2008. - Vol. 248, №. 6. - P. 1074-1080.

12. Organ failure and infection of pancreatic necrosis as determinants of mortality in patients with acute pancreatitis/ M. S. Petrov, S. Shanbag, M. Chakraborty [ et al.] // Gastroenterology. - 2010. - Vol. 139. - P. 813-820.

13. Petrov M. S. Infected pancreatic necrosis: not necessarily a late event in acute pancreatitis / M. S. Petrov, V. Chong, J. A. Windsor // World J. Gastroenterol. - 2011. - Vol. 17. - P. 3173-3176. 14. Surgical management and complex treatment of infected pancreatic ne crosis: 18-year experience at a single center / G. Farkas, J. Marton, Y. Mandi [et al.] // J. Gaslrointest. Surg. 2006. - Vol. 10. - P. 278-285. 